\title{
Vygotsky and Lenin on Learning: The Parallel Structures of Individual and Social Development
}

\begin{abstract}
WAYNE AU
ABSTRACT: Study of Lenin and Vygotsky's theoretical explorations of social and individual development reveals Vygotsky's conception of conscious awareness and scientific concepts as directly correlated with Lenin's conception of consciousness. Following from this core idea, similarities are demonstrated between Lenin's conception of the role of political leadership in the development of working-class consciousness and the role of Vygotsky's teacher or "more capable peer" in the development of "conscious awareness." Finally, Vygotsky's methodological leap in his conception of individual development is best understood when situated within Lenin's concept of social development. Vygotsky is thus re-established as operating within the Marxist-Leninist political and philosophical tradition.
\end{abstract}

OVIET PSYCHOLOGIST LEV VYGOTSKY has been hailed as the "Mozart of Psychology" (Toulmin, 1978) and as "one of the $\bigcirc$ great theory makers of the first half of the [20th] century" (Bruner, 1987). Even though he completed his work in the 1920s and 30s, as ongoing testament to the power of his theorizing, Vygotsky's theories and findings have been used with great success in contemporary settings (see Karpov, 2003; Meacham, 2001; Chaiklin, 2003). When Vygotsky's Thought and Language (1962) was first translated and edited into English, most of his original references to Marx and Engels, and all references to Lenin, were summarily omitted (Graham, 1972). The revised and edited edition by Kozulin (Vygotsky, 1986) corrected this problem by reinserting Vygotsky's references to 
Marx, Engels, and Lenin, and included more of the original text than its 1962 predecessor. Representative of Cold War politics, the nearly 25-year gap in translations seems to have alienated Vygotsky from Marxism for some readers, and for many in education. ${ }^{1}$ However, in an unpublished notebook Vygotsky himself wrote:

I want to find out how science has to be built, to approach the study of the mind having learned the whole of Marx's method. ... In order to create such an enabling theory-method in the generally accepted scientific manner, it is necessary to discover the essence of the given area of phenomena, the laws according to which they change, their qualitative and quantitative characteristics, their causes. It is necessary to formulate the categories and concepts that are specifically relevant to them - in other words, create one's own Capital. (Vygotsky, as quoted in Cole \& Scribner, 1978, 8.)

It would seem that Vygotsky's concepts did actively grow from the Marxist, dialectical materialist tradition of analysis of science and society. While this fact is recognized by some scholars within educational psychology (Blanck, 1990; Newman \& Holzman, 1993; Cole and Scribner, 1978; Graham, 1972; Wertsch, 1985; Bruner, 1984; Rosa and Montero, 1990), Vygotsky is less well known for his connection to Lenin. Even though some scholars have noted that Vygotsky made use of Lenin's "theory of reflection" (Wertsch, 1985) and activity (Davydov, 1988a), and Vygotsky himself referenced Lenin in his work (Vygotsky, 1987), Vygotsky is not commonly recognized as working as part of the Marxist-Leninist theoretical tradition. However, the theoretical-conceptual relationship between Lenin and Vygotsky becomes clear upon examining Vygotsky's conceptualization of human development in his work "The Development of Scientific Concepts in Childhood" (Vygotsky, 1987, ch. 6) and "Interaction Between Learning and Development" (Vygotsky, 1978) among others, in comparison with Lenin's conception of social/political development from his text What Is to Be Done? (Lenin, 1975). ${ }^{2}$

1 The 1987 translation by Norris Minnick, re-titled as Thinking and Speech (Vygotsky, 1987), has provided an even more complete and nuanced translation of Vygotsky's work, and it is the translation that I have used as standard for this paper.

2 In drawing a parallel between Lenin's conceptual framework for the development of the consciousness of workers with Vygotsky's conceptual framework for the development of conscious awareness in students, this paper in no way implies that the workers are childlike or that Lenin or Vygotsky viewed workers as children. The intention here is to show the correlation between these two frameworks and make the argument that they were both providing a conception of how consciousness develops generally. 
In order to draw the theoretical-conceptual connections between Lenin and Vygotsky, the discussion will proceed as follows: First, Lenin and Vygotsky's theoretical explorations of social and individual development will be discussed to delineate the parallels between the two essentially drawing and comparing the conceptual maps of both. Second, Vygotsky's "scientific concepts" and "spontaneous concepts" will be shown to have a parallel structure with Lenin's "conscious" and "spontaneous" working-class consciousness. The argument will be made that Vygotsky elaborated and developed Lenin's framework into a theoretically complex analysis of the relationship between "scientific" concepts and the "zone of proximal development." Third, similarities between Lenin's conception of the role of political leadership in the development of working-class consciousness and the role of Vygotsky's teacher or "more capable peer" in the development of "conscious awareness" will be made clear. Fourth, the methodological leap that Vygotsky made in order to connect his conception of individual development with that of Lenin's social development will be highlighted as a novel incorporation of a Marxist-Leninist conceptual framework into psychology. Finally, the conclusion will discuss some of the key questions and issues raised by the position presented here.

\section{Lenin: Consciousness and Spontaneity}

Consciousness is, therefore, from the very beginning a social product, and remains so as long as [humans] exist at all. Consciousness is at first, of course, merely consciousness concerning the immediate sensuous environment and consciousness of the limited connection with other persons and things outside the individual who is growing self-conscious. (Marx and Engels, 1978, 158.)

In his work organizing for the socialist revolution in Russia, Lenin was deeply committed to developing an understanding of how the working class came to "consciousness" as a class within a system of exploitation. This issue alone was the basic impetus for What Is to Be Done? (Lenin, 1975), which Lenin wrote specifically to engage in an ideological struggle with other political organizations about which organizing strategy would lead to a socialist revolution. Lenin praises the newspaper Rabochye Dyelo for raising the general issue of the "different appraisals of the relative importance of the spontaneous and consciously 'methodical' element" (34) as a key to understanding the 
theoretical and political differences that existed among Russian Social Democrats at the time. He explains: "That is why the question of the relation between consciousness and spontaneity is of such enormous general interest ..." (35). Thus Lenin turned to exploring the relationship between what he termed "spontaneous" revolts and "conscious," organized strategic actions by workers and their relationship to class consciousness and the socialist revolution in Russia.

Although Lenin never explicitly lays out his definition of consciousness in What Is to Be Done?, one emerges from the text as he discusses the labor movement of the time. Lenin talks historically about the St. Petersburg strikes of 1896 as being an earlier example of a spontaneous movement, but one that spread throughout Russia and took on the "wholesale character" of a deepening understanding of Marxism. Lenin contrasts this type of action with that of the strikes in the 1860s and 70s, where there was the "spontaneous" destruction of machinery. These he qualifies as "riots" in contrast with the "conscious" St. Petersburg strikes marking the progress of the "working-class movement of that period" (36). "Riots," in Lenin's terms, then, are spontaneous worker uprisings where machinery is destroyed, but in a non-systematic manner and without pre-formulated long-term goals or strategic plans.

Lenin distinguishes between the two types of strikes further still, analyzing the relationship between "spontaneity" and "consciousness." He sees the "riots" of the 1860s and 70s as an early expression of an "awakening of consciousness" that were "outbursts of desperation and vengeance" (36) more than anything else. However, he sees the strikes of the 1890s as revealing "far greater flashes of consciousness" since "definite demands were advanced, the strike was carefully timed, known cases and examples in other places were discussed ..." $(1975,36)$. He goes on to say that "while the riots were simply revolts of the oppressed, the systematic strikes represented the class struggle in embryo" (36), claiming that, "this shows that the "spontaneous element,' in essence, represents nothing more nor less than consciousness in an embryonic form" (36). Lenin summarizes what he sees happening in the workers' movement, and identifies the distance he sees between their spontaneous "awakening" and their consciousness of the entire "social system":

Taken by themselves, these strikes were simply trade union struggles, but not yet Social-Democratic struggles. They testified to the awakening antago- 
nisms between workers and employers, but the workers were not, and could not be, conscious of the irreconcilable antagonism of their interests to the whole of the modern political and social system, i.e., theirs was not yet SocialDemocratic consciousness. (36.)

Later, in discussing how student movements develop and get crushed "spontaneously," Lenin points out that these actions usually end in wholesale arrests, "precisely because these open hostilities were not the result of a systematic and carefully thought-out and gradually prepared plan for a prolonged and stubborn struggle ..." (124-5).

For Lenin (1975), the goal was to move workers towards what he framed as a "genuine class consciousness" built on a "materialist analysis" of the social world around them, in order to develop a movement of workers that was explicitly "conscious" of how the social, political, and economic systems were operating in direct contradiction to the workers' interests. He elaborates:

The consciousness of the masses of the workers cannot be genuine class consciousness . . . unless they learn to apply in practice the materialist analysis and the materialist estimate of all aspects of the life and activity of all classes, strata and groups of the population. (86.)

Lenin goes on to discuss "conscious" thought regarding the growing working-class movement in terms of working with people to develop abstract generalizations about concrete social conditions where "it is possible to 'begin' only by inducing people to think about all these things, by inducing them to summarize and generalize all of the diverse signs of ferment and active struggle" (200).

Based on the text, we can then see Lenin's definition of "conscious" worker uprisings as "systematic" and "methodical"; with "known cases ... discussed" and "definite demands . . advanced"; working with a "gradually prepared plan" that is "carefully thought-out" and strikes that are "carefully timed"; with workers being able to "apply . . . materialist analysis," "summarize and generalize," and to see their "antagonism to ... the whole social system." In the most general sense, to be "conscious" in Lenin's terms means to be thought-out, planned, self-aware, and using systematic analysis to develop strategy and take action as part of a larger working-class movement against a system that is not operating in the interests of workers. In the specific context 
within which Lenin is working - pre-socialist Russia - his rhetoric is aimed towards workers developing consciousness as-a-class (Burke, 1950) so that their strikes, rebellions, and revolts can become strategically planned acts of uprising, consciously enacted as a part of the broader working-class movement, with the explicit revolutionary aim of overthrowing the Tsarist government and establishing a socialist state. Lenin's argument is that this consciousness is absolutely necessary if workers are to be able to achieve liberation from their exploitation in Russia through socialism, an argument he made specifically against the "economists" who were advocating a focus solely on workers' immediate rights and not on the overthrow of the exploitative economic and social system as a whole.

We can thus summarize what Lenin's general conception of "consciousness" might be: the willful application of a systematic and materialist analysis of social conditions and relations, making use of summation and generalization as forms of abstraction for understanding what is happening in the world in preparation for purposeful, volitional action to change that world. This conception fits well within Marx' and Engels' own ideas regarding a materialist development of consciousness and ideas (Marx and Engels, 1978):

We set out from real, active [humans], and on the basis of their real lifeprocess we demonstrate the development of the ideological reflexes and echoes of this life-process. The phantoms formed in the human brain are also, necessarily, sublimates of their material life-process, which is empirically verifiable and bound to material premises. ... Life is not determined by consciousness, but consciousness by life. (154-155.)

The idea that consciousness arises from human activity "on the basis of their real life-process" becomes a foundational concept for the field of "activity theory," of which Vygotsky is considered to be a founder (Davydov, 1988b).

\section{Vygotsky: Conscious Awareness and Scientific Concepts}

Conscious awareness is an act of consciousness whose object is the activity of consciousness itself. (Vygotsky, 1987, 190.)

Vygotsky's conception of "conscious awareness" directly follows that of Lenin's “consciousness." The importance of this conception 
cannot be overstated, as it becomes the cornerstone of Vygotsky's theorizing, including his conceptualization of "scientific concepts" and the "zone of proximal development." Vygotsky asserts:

If conscious awareness means generalization, it is obvious that generalization, in turn, means nothing other than the formation of a higher concept in a system of generalization that includes the given concept as a particular case. ... Thus, the generalization of the concept leads to its localization within a definite system of relationships of generality.... Thus at one and the same time, generalization implies the conscious awareness and the systematization of concepts. $(1987,192$.

Much like Lenin, Vygotsky associates conscious awareness with both generalization and the systematization of thinking. While Lenin writes specifically about the workers' developing consciousness of how the "whole social system" functions so that they can change it, Vygotsky writes more generally about how understanding the system of concepts allows one to gain "mastery" over its use.

In a certain sense, any generalization or abstraction isolates its object. This is why conscious awareness - understood as generalization — leads directly to mastery... . Thus, the foundation of conscious awareness is the generalization or abstraction of the mental processes, which leads to their mastery. (190-1.)

After establishing the link between conscious awareness and generalization or understanding within a system of concepts, Vygotsky then makes the connection between conscious awareness and what he terms "scientific concepts."

It is apparently in this domain of the scientific concept that conscious awareness of concepts of the generalization and mastery of concepts emerges for the first time... . Thus, conscious awareness enters through the gate opened by the scientific concept. (190-1.)

Vygotsky further buttresses the connection between scientific concepts and conscious awareness by stating that "because it is scientific in nature, the scientific concept assumes some position within a system of concepts. This system defines the relationship of scientific concepts to other concepts" (192-3). Thus, building on a Leninist 
conception of consciousness discussed above, Vygotsky develops the idea of "scientific" concepts and their counterpart "everyday" or "spontaneous" concepts.

\section{Everyday and Scientific Concepts}

We must explore the common characteristics of the processes involved in the formation of scientific concepts and those involved in the formation of the concepts that ... emerge from the child's own everyday life experience; we will refer to the latter as everyday concepts. (Vygotsky, 1987, 172.)

Although Vygotsky never directly defines what scientific concepts are, he does define them through textual references and in relation to what they are not: everyday or spontaneous concepts. ${ }^{4}$ As noted in the above quote, Vygotsky sees "everyday concepts" as those that develop from day-to-day life experiences. Further, Vygotsky describes everyday concepts as being "characterized by a lack of conscious awareness" (Vygotsky, 1987, 191). This is not to say that we walk around and experience our everyday lives while asleep and unconscious. We are conscious; we are awake and we make decisions. Rather, Vygotsky is interested in how "conscious awareness" develops as "an act of consciousness whose object is the activity of consciousness itself" (Vygotsky, $1987,190)$. So to be consciously aware is to be actively conscious of your consciousness (thinking about your thinking) in a systematic way. This is the same way Lenin conceptualized workers' class consciousness. Workers were conscious of their own conditions and were upset about everyday work conditions - hence the unplanned "riots." But they did not necessarily have a meta-consciousness of their own con-

3 Although there is not enough space to fully address the issue here, it should be noted that Vygotsky's use of the terms "science" and "scientific" are most likely quite different than what these terms are regularly accepted to connote. In current usage, the term "science" commonly serves as a marker for what we know as the positivistic sciences. The positivistic conception of science is quite problematic for a wide range of reasons. Suffice to say, if we accept the proposition that Vygotsky worked within the Marxist tradition, then we have to also accept the proposition that he was working within a dialectical materialist conception of science - one that is in many ways antithetical to the positivistic conception.

4 It should be noted that throughout the text of Thinking and Speech, Vygotsky uses "nonspontaneous" and "scientific" somewhat interchangeably in reference to concepts; "spontaneous" and "everyday" are used interchangeably as well. However, the text does seem to assert that "scientific" concepts are more specific types of "nonspontaneous" concepts. 
sciousness and its systematic relation to their position within the Russian economic, political, and social structures; instead, they were reacting on their everyday concepts and not applying a more systematized "scientific" analysis to both their position and their actions.

For Vygotsky a systematized understanding of our conscious relationships with the material world is important because such conscious awareness allows us to see "supra-empirical connections" between concepts within a system, thus establishing a new relationship between the concept and the object being conceived (Vygotsky, 1987). Vygotsky's framing of how a systematic understanding builds new relationships and leads to the ability to see "supra-empirical connections" mirrors that of Lenin, who is in part concerned with the ability of workers to understand "supra-empirical connections" between their immediate struggles and their relationship to the social and economic system of Tsarist Russia as a whole. As discussed above, Lenin (1975) is concerned with workers developing consciousness of their relationship to the political and social system as a whole, in essence asserting that workers not only need to focus on their day-to-day "trade union struggles" (36), such as better pay and improved working conditions. Additionally, Lenin asserts that workers need to see their relationship to the social and economic system in a new way (thus his lengthy reference to the necessity of dreaming of a new future), and to understand that their contradiction is not only with their employers over everyday work conditions but with the whole system. To do so is to become conscious of the "supra-empirical connections" among the workers themselves, their condition as a class, and their relationship to a social-economic system that exploits their labor, and it is this understanding, this form of "consciousness," that would be required for workers to take collective revolutionary action against that system.

Vygotsky supports this developmental need to see relationships in new ways when he claims: "In receiving instruction in a system of knowledge, the child learns of things that are not before his eyes, things that far exceed the limits of his actual and or even potential immediate experience" $(1987,180)$. The learning of scientific concepts, of concepts learned within a system, allows us to see things that we did not necessarily see before in the immediacy of our everyday lives. We may learn something new about an object we've taken for granted on a day-to-day basis, or we may learn something new about an object that we have never actually physically experienced. This is 
the power of "receiving instruction in a system of knowledge." New horizons are opened up in our conceptual development, and old horizons may be recast to provide new conceptual development as well. Further, for Vygotsky, the ability to learn new things and see things differently is of critical importance because such vision creates the ability to conceptualize new relationships and therefore different actions in respect to the object of study: "To perceive something in a different way means to acquire new potentials for acting with respect to it. ... By generalizing the process of activity itself, I acquire the potential for new relationships with it" (190). The key question for Vygotsky, then, is how do concepts develop? He begins to find his answer in the relationship between spontaneous and scientific concepts.

\section{The Relationship Between Spontaneous and Scientific Concepts}

Vygotsky strongly asserts that spontaneous and scientific concepts are not actually separate, in that they do not maintain individual identity as singular concepts on individual paths of development. In fact, Vygotsky sees spontaneous and scientific concepts as being dialectically related: "Whether we refer to the development of spontaneous concepts or scientific ones, we are dealing with the development of a unified process of concept formation" (Vygotsky, 1987, 177). For Vygotsky, spontaneous and scientific concepts are interrelated, interdependent, and influence each other greatly due to the fact that "the learning of a system of scientific concepts presupposes the widely developed conceptual fabric that has emerged on the basis of the spontaneous activity of the child" (180). To some degree, scientific concepts depend on the level of development of spontaneous concepts. Similarly, the development of scientific concepts impacts the structure and development of spontaneous concepts. The relationship between scientific and spontaneous concepts is key to Vygotsky's framework, and he explains that

the development of scientific concepts begins in the domain of conscious awareness and volition. It grows downward into the domain of the concrete, into the domain of personal experience. In contrast, the development of spontaneous concepts begins in the domain of the concrete and empirical. It moves toward the higher characteristics of concepts, toward conscious awareness and volition. The link between these two lines of development 
reflects their true nature. This is the link of the zone of the proximal development and actual development. . . Scientific concepts restructure and raise spontaneous concepts to a higher level, forming their zone of proximal development. $(1987,220$.

The last sentence of this passage identifies an important point in understanding Vygotsky's conception of development. Scientific concepts, as they raise spontaneous concepts from the level of actual development toward conscious awareness, lead directly to the creation of the zone of proximal development.

Again, Vygotsky's conception of development follows that of Lenin. As discussed earlier, Lenin saw the spontaneous strikes and worker revolts as being "consciousness in embryonic form" and as an "awakening" to the contradictory interests between the workers and the employers. Both of these references point to the idea that the spontaneous consciousness of the workers around economic issues played an important and necessary part in the development of their consciousness as workers, and that this spontaneous consciousness held the potential — with strategic leadership — to develop into "Social-Democratic" consciousness, explicitly aimed at establishing a revolutionary socialist state. Lenin addresses this as follows:

Everyone agrees that it is necessary to develop the political consciousness of the working class. The question is, how is that to be done, what is required to do it? The economic struggle merely "brings home" to the workers questions concerning the attitude of the government towards the working class. $(1975,97$.

By raising the above issues, Lenin is addressing how the "everyday" experiences of the workers, their spontaneous conceptions of their experiences, are an important part of the development of a more scientific consciousness of the workers' movement. In Lenin's conception, a certain level of spontaneous awareness was absolutely necessary for workers in Russia to develop a more "conscious" understanding of their position as workers in relation to a broader movement and a

5 It should be noted that Lenin's use of the term "Social Democracy" was different from the way it is popularly used now. For Lenin, Social Democrats were interested in a socialist revolution that included the overthrow of the ruling class and the complete restructuring of the state. More contemporary usages of the term refer to the idea of using existing liberal democracies to support socialist ideals and policies. 
broader social system. In this regard, the workers' spontaneity had certain strengths and certain potentials which Lenin saw and which the Social Democrats of the time seized upon. Indeed, in Vygotskian terms, it could be said that Lenin saw a zone of proximal development in the spontaneous consciousness of the workers.

\section{The Zone of Proximal Development}

and the Actual Level of Development

Vygotsky was interested in explaining the dialectical movement between spontaneous and scientific concepts as part of an exploration of learning more generally. Vygotsky saw this process expressed as the relationship between instruction and development.

In essence, the problem of nonspontaneous concepts - of scientific concepts in particular - is the problem of instruction and development. Spontaneous concepts create the potential for the emergence of nonspontaneous concepts in the process of instruction. Instruction is the source of the development of this new type of concept (Vygotsky, 1987, 194).

Much like his conception of the relationship between spontaneous and scientific concepts, Vygotsky framed the relationship between instruction and development as "two processes with complex interrelationships" (201) and extends his discussion to assert that "the zone of proximal development - which determines the domain of transitions that are accessible to the child - is a defining feature of the relationship between instruction and development" (211). The "zone of proximal development" (hereafter ZPD) is at the heart of the relationship between instruction and development and is one of Vygotsky's most widely accepted and widely used concepts. He most succinctly defines it in his essay "Interaction Between Learning and Development" (Vygotsky, 1978) as

the distance between the actual development level as determined by independent problem solving and the level of potential development as determined through problem solving under adult guidance or in collaboration with more capable peers. (86.)

Although there are some nuanced differences, this definition is conceptually consistent with the one he provides in Thinking and Speech 
(Vygotsky, 1987, 209). ${ }^{6}$ In some respects, the ZPD seems like common pedagogic sense for teachers because, as Vygotsky points out, one starts where the student already "is," at the "actual level of development" (hereafter ALD), and see how far they can progress into the ZPD with the aid of a teacher or "more capable peer." Within the Vygotskian conception, the ZPD is "an essential feature of learning" that "awakens a variety of internal developmental processes that are able to operate only when the child is interacting with people in his environment and in cooperation with his peers" (Vygotsky, 1978, 90). Additionally, Vygotsky explains that the ZPD and the ALD are dialectically related in that one transforms into the other.

What lies in the zone of proximal development at one stage is realized and moves to the level of actual development at a second. In other words, what the child is able to do in collaboration today he will be able to do independently tomorrow. Instruction and development seem to be related in the same way that the zone of proximal development and the actual level of development are related (Vygotsky, 1987, 211).

It is worth noting that the ZPD does not extend infinitely in front of any one learner and any given time. Vygotsky (1987) notes that learners are "restricted to limits which are determined by the state of [their] development and [their] intellectual potential.... There always exists a definite, strictly lawful distance that determines the differential between [their] performance in independent and collaborative work" (209). In this sense Vygotsky advocates that teachers and "more capable peers" always be looking forward, ahead of the ALD, in their instruction, but if we look too far forward and teach beyond the ZPD, then our instruction will not necessarily serve development.

\section{Working-Class ALD and ZPD}

Vygotsky's conception of the ZPD and ALD also has a corollary within Lenin's conception of the development of the consciousness of workers. In the context of the strikes taking place in pre-socialist Russia, Lenin sees that the workers had a particular level of spontaneous

6 In his definition in Thinking and Speech, Vygotsky only refers to the role of teachers and does not refer to "more capable peers." Further, he does not include the "level of potential development" in Thinking and Speech, but he does refer to the "level of intellectual potential." 
understanding regarding their actions. He uses the term "economic struggle" to connote the same focus on immediate work conditions without a more general focus on the social and economic system as a whole. In a very Vygotskian sense, Lenin is asserting that if the consciousness of the workers is kept "within the framework of the economic struggle," then revolutionary, Social-Democratic progress will not be made. For Lenin, the "economic struggle" was at the ALD of workers' consciousness; remaining at that level would not lead to increased development of the consciousness required to end systematic exploitation. Lenin saw that, given the level of spontaneous worker responses to their antagonism with their employers, the development of "political consciousness" (as Lenin put it) or "conscious awareness" (as Vygotsky put it) was within the ZPD of the working class at the time. For Lenin, this meant that spontaneous consciousness had reached a level where socialist revolution was tangibly within their grasp, and that strategic, systematic leadership was necessary in order to make the qualitative leap in both consciousness and social structure.

Lenin aptly summarizes the process of working-class consciousness moving through the ZPD with the aid of a teacher or "more capable peer" in the following passage:

Hence, we had both the spontaneous awakening of the masses of the workers, the awakening to conscious life and conscious struggle, and a revolutionary youth, armed with the Social-Democratic theory, eager to come into contact with the workers. In this connection it is particularly important to state the oft-forgotten (and comparatively little-known) fact that early SocialDemocrats of that period zealously carried on economic agitation ... but they did not regard this as their sole task. On the contrary, right from the very beginning they advanced the widest historical tasks of Russian SocialDemocracy in general, and the task of overthrowing the autocracy in particular. $(1975,36-7$.

We can identify all of the major components of Lenin's and Vygotsky's respective theories of social and individual development within this rich quote. To begin, the "spontaneous awakening" of the workers to "conscious life and conscious struggle" is a remark about their ALD, the level of spontaneity upon which a more conscious or scientific conception can be built. We can also identify the role of leadership within Lenin's reference to the "revolutionary youth, armed with the 
Social-Democratic theory," who, while beginning at the workers' ALD with "economic agitation," sought to move them through the ZPD to "the widest historical tasks of Russian Social-Democracy in general, and the task of overthrowing the autocracy in particular." This also speaks to the relationship that Lenin and Vygotsky saw between consciousness and the ability to form system-wide or "supra-empirical" connections. In this case the "revolutionary youth" kept the "supraempirical" connections in mind from the beginning of their work, and by implication they were working to move the workers to understanding the entire system of relationships in which they were embedded. While it is obvious that Vygotsky's conception was pedagogical in nature, what I've done here points to the fact that Lenin's conception of development was pedagogical as well. Development and instruction were/are indeed intertwined with the ALD and ZPD. The ultimate goal, of course, was for the workers to be able to do independently tomorrow (i.e., develop consciousness) what they did "in collaboration" with revolutionary leadership today. A comparative explanation of both Lenin's and Vygotsky's conceptions of leadership will demonstrate their congruency as well as help develop a nuanced discussion of the relationship between teaching, political leadership, and the development of consciousness.

\section{Teachers, Political Leadership, and "More Capable Peers"}

In Lenin's analysis, the workers would only gain consciousness - that is systematic understanding of their class position and class strategies for socialist revolution - with the aid of political leadership that, in part, comes from outside of the working class itself. This is one of Lenin's most controversial assertions, and it has been interpreted in varying and often contradictory ways (Shandro, 1995). For Lenin, the development of revolutionary consciousness could not happen (and historically did not happen) without the assistance of a group of people, an organization, whose specific job was to make revolution - including doing educative, consciousness-raising work among the working class itself. This was a strategic, necessary stance on Lenin's part, and its ultimate goal was an emancipated, anti-capitalist working class. Shandro (1995) re-casts Lenin's argument in terms of two distinct claims: 
first, that the working-class movement cannot establish a position of strategic independence vis-à-vis its adversaries without attaining a recognition of the irreconcilability of its interests with the whole politico-social system organized around the dominance of bourgeois interests; second, that such recognition cannot be effectively brought to bear upon the class struggle in the absence of an organized leadership informed by Marxist theory. (285.)

A key issue, then, is how Lenin defines the make-up of the political leadership. Are political leaders a group of intellectuals telling the working class how to make a socialist revolution? Or are they, in Vygotsky's terms, teachers and/or "more capable peers" in part made up of and working with the working class to develop conscious awareness?

Based on a reading of both Lenin's and Vygotsky's texts, it would seem that Vygotsky's conception of leadership in relation to the ZPD mirrors Lenin's conception of political leadership in relation to the development of revolutionary consciousness among workers. In What Is to Be Done? Lenin discusses how consciousness can only develop with the help of outside leadership. He states that Social-Democratic consciousness

could only be brought to [the workers] from without. The history of all countries shows that the working class, exclusively by its own effort, is able to develop only trade union consciousness, i.e., the conviction that it is necessary to combine in unions, fight the employers and strive to compel the government to pass necessary labour legislation, etc. The theory of Socialism, however, grew out of the philosophic, historical and economic theories that were elaborated by the educated representatives of the propertied classes, the intellectuals. ... In the very same way, in Russia, the theoretical doctrine of Social-Democracy arose quite independently of the spontaneous growth of the working class movement... (37.)

One of the central issues is that of consciousness being developed "only from without." This phrasing has been interpreted to mean that a vanguard is a group of disconnected, outside intellectuals who will intervene and tell the workers how to save themselves. A closer, more extended reading of Lenin's text says otherwise, however. For Lenin, the necessary political leadership comes from a group of "people who are professionally engaged in revolutionary activity" (136). He later adds: "the organizations of revolutionaries must consist first, foremost 
and mainly of people who make revolutionary activity their profession" (138). It literally is the political leadership's "job" to consciously come to a systematic, materialist understanding of what is happening and make strategic decisions and take strategic actions towards making a revolution - including developing the consciousness of the workers. This is their main focus, their "profession," and it is a defining characteristic of Lenin's conception of political leadership.

In terms of the make-up of this leadership, Lenin is equally clear that it is not just a group of people outside of the working classes when he says: "the spontaneously awakening masses will advance from their own ranks increasing numbers of 'professional revolutionaries'” (136, emphasis added). Intellectuals are also considered an important part of the revolutionary leadership, but Lenin does not import them wholesale as pre-qualified leaders. In fact, he asserts that "the masses will never learn to conduct political struggle until we help to train leaders for this struggle, both from among the enlightened workers and from among the intellectuals ..." (199, emphasis added). Lenin does not assume that the intellectuals automatically know how to take on political leadership, and it is clear that he feels they will need training in the same sense that the leadership from the workers will need training. In regard to the political leadership mainly being a group committed to revolutionary activity, Lenin adds: "In view of this common feature of the members of such an organization, all distinctions as between workers and intellectuals, and certainly distinctions of trade and profession, must be utterly obliterated" (138). He goes on to say that "we must have a committee of professional revolutionaries and it does not matter whether a student or a worker is capable of becoming a professional revolutionary" (150). So while Lenin is concerned with the fact that the leadership be made up of both workers and intellectuals, the leadership's sole concern is how to carry out revolutionary change, regardless of their position as worker or intellectual per se.

Vygotsky's conception of leadership - in the form of a teacher or "more capable peer" - as playing a defining role as a student moves through the ZPD follows Lenin's conception of working-class development with the assistance of political leadership made up of both intellectuals and workers. The importance of the teacher and "more capable peer" in Vygotsky's conception of learning cannot be overstated. For him, having another, more knowledgeable person aid 
the learner's development was absolutely necessary if the learner was going to be able to move into the ZPD and develop scientific concepts:

In a problem involving everyday concepts he must do with volition something that he does with ease spontaneously. In a problem involving scientific concepts, he must be able to do in collaboration with the teacher something that he has never done spontaneously. (Vygotsky, 1987, 216.)

In a way, it seems commonsensical to say that, as individuals, we cannot know everything there is to know, and that therefore we can learn more if we work together and share specific expertise and understanding. More importantly, the role of the teacher or more capable peer is in part defined by their ability to assess where a learner is developmentally, thus allowing them to shape instruction to fall within the ZPD. This frames the teaching act, or the act of revolutionary leadership, as a means of working with others within their ZPD in the process of dialectically moving between spontaneous concepts and scientific concepts.

To be sure, there is room for interpretation as to how the educative relationship could and should function. Vygotsky himself was absolutely clear that students do not learn by rote memorization. He states: "scientific concepts are not simply acquired or memorized by the child and assimilated by his memory but arise and are formed through an extraordinary effort of his own thought" (Vygotsky, 1987, 176), and contemporary scholars have argued that Vygotsky did not advocate the use of a simple "transmission" model of learning (see John-Steiner \& Mahn, 1996). Indeed, if we envision the ZPD not as a static zone to pass through or reach the end of, but rather as the continual unfolding of a zone of development that extends just beyond the growing, ever-developing ALD of the student, then we are more prone to understand teaching as an active, process-oriented relationship with ebbs and flows, growth and stagnation, leaps and pauses. To envision the ZPD of a student in such a way, a way that embraces learning and teaching as intertwined, dynamic, dialectical processes, does not allow for a simple transmission model of education. Rather, such a pedagogical vision requires that we be studentcentered in our understanding of where a student is developmentally, by building our instructional relationships based on that level of 
development, and by using ongoing, concentric feedback loops for the teacher or more capable peer to continually assess where a given student's ALD and ZPD may lie. Additionally, we must remember that teachers, as developing individuals themselves, also have their own ALD and ZPD with regard to their understanding of both their teaching practice and their students. To recognize this also challenges the use of transmission models of teaching and learning within Vygotsky's framework because it assumes that teachers themselves are also learning, developing, and growing. As Freire $(1974 ; 1982)$ correctly argues, such a conception of teaching and learning does not allow for didactic forms of instruction. Because neither teacher nor student are perfectly formed, all involved in educative relationships are in the process of learning and re-learning themselves and each other.

It is arguable that Lenin also did not see the development of workers' consciousness as an act of didactic, one-way transmission, and therefore did not advocate for the Social-Democratic political leadership to merely transfer their knowledge into the heads of the working class. In a footnote in What Is to Be Done?, Lenin discusses this issue in relation to the role of workers in creating socialist ideology:

This does not mean, of course, that the workers have no part in creating such an ideology. But they take part not as workers, but as socialist theoreticians . . ; in others words, they take part only when, and to the extent that they are able, more or less, to acquire the knowledge of their age and advance that knowledge. And in order that workingmen may be able to do this more often, every effort must be taken to raise the level of the consciousness of the workers generally; the workers must not confine themselves to the artificially restricted limits of "literature for workers" but should learn to master general literature to an increasing degree. It would even be more true to say "are not confined," instead of "must not confine themselves," because the workers themselves wish to read and do read all that is written for the intelligentsia and it is only a few (bad) intellectuals who believe that it is sufficient "for the workers" to be told a few things about factory conditions, and to have repeated to them over and over again what has long been known. (48.)

Similar to his conception of workers taking active part in political leadership, Lenin saw them as taking part as "socialist theoreticians" who indeed were interested in reading and thinking about what was to be done in Russia at the time. We should also note Lenin's above 
critique of "bad" intellectuals who believe in dogmatic exposition of the workers' struggles to the workers themselves. Clearly Lenin did not think workers were stupid, and he did not approve of intellectuals who viewed them as such. Perhaps even more important is Lenin's insistence that "every effort must be taken to raise consciousness" for workers to be able to take up study on their own - again, a conceptual corollary that fits well with Vygotsky's ALD and ZPD.

\section{The Social Mind: Vygotsky's Methodological Leap}

To paraphrase a well-known position of Marx's, we could say that humans' psychological nature represents the aggregate of internalized social relations that have become functions for the individual and forms of his/her structure (Vygotsky, 1981, 164).

It is the above theoretical point, one which he found support for in his own research, that provides the key methodological connection between Vygotsky and Lenin. Essentially, Vygotsky's theorizing represents a scaled-down version of Lenin's conceptual framework in which Lenin's social/macro analysis correlates to Vygotsky's own individual/micro analysis. This scaling down can be seen in one of Vygotsky's most fundamental claims: that the structure of external social relations becomes internalized and in turn structures the "higher mental functions" of the individual.

In his essay "The Genesis of Higher Mental Functions" (Vygotsky, 1981), Vygotsky identifies "higher mental functions" in the following ways. First, he refers to Buhler's model of "three stages in the development of behavior" (154), the highest and final stage of which is "the stage of intellect or intellectual responses that fulfill the function of adaptation to new conditions" (154). In this regard, Vygotsky seems to be using "higher mental functions" to refer to thought-out, conscious responses to the environment (in a most materialist sense) and as a step "above" reflexive reactions. Later in the same essay, Vygotsky discusses his idea that at "higher" levels of development "mediated relations among people emerge. The essential feature of these relations is the sign, which aids in establishing this social interaction" (160). It is through signs (i.e., language) that humans interact socially, and for Vygotsky the use of these signs, as well as the social interactions themselves, are representative of "higher" or more complex forms of development. In this way Vygotsky essentially extends 
Engels' materialist conception of human-environment interactions to include the use of tools, such as sign systems, as a mediating factor in development (Engels, 1940; cf. Cole and Scribner, 1978). Vygotsky ultimately arrives at the conclusion: "Any higher mental function necessarily goes through an external stage in its development because it is initially a social function" $(1981,162)$, and then associates "voluntary attention, logical memory, the formation of concepts, and the development of volition" (163) as appearing on the "social plane" before being internalized, which, following his logic, are defined as "higher mental functions" themselves. Vygotsky's discussion in "The Genesis of Higher Mental Functions" is consistent with his work in Thinking and Speech (Vygotsky, 1987), where it is clear that he associates higher forms of mental development with "conscious awareness" and regularly refers to "volition" as an aspect of that development.

Vygotsky took great pains to make his central point, that the structure of external social relations becomes internalized and in turn structures the "higher mental functions" of the individual, in several different settings and studies. In his theorizing about cultural development in children, he asserts: "The child, after mastering the structure of some external method, constructs the internal processes according to the same type" $(1929,427)$. Later he integrates the role of signs as mediating tools in the cultural development of children, writing:

If it is correct that the sign initially is a means of social interaction and only later become a means of behavior for the individual, it is quite clear that the cultural development is based on the use of signs and their inclusion in a general system of behavior that initially was external and social. In general, we could say that the relations among higher mental functions were at some earlier time actual relations among people. (Vygotsky, 1981, 158.)

Vygotsky extends his thinking further in the same piece, formulating a "law of cultural development" which states: "Any function in the child's cultural development appears twice. ... First it appears between people as an interpsychological category, and then within the child as an intrapsychological category" (Vygotsky, 1981, 162). Wanting to make sure his point is not lost, he summarizes as follows:

the very mechanism underlying higher mental functions is a copy from social interaction; all higher mental functions are internalized social relationships. These higher mental functions are the basis of the individual's social 
structure. Their composition, genetic structure, and means of action - in a word, their whole nature — is social. (164.)

In Vygotsky's conception, the individual is the social and the social is the individual, and social structures impact the cognitive structures of the individual. Although not explicitly linked to Vygotsky, this particular argument has been fruitfully addressed in more contemporary scholarship (see Bourdieu, 1984; Bernstein, 1996; Nash, 2005). Lenin provides the other side of the conceptual coin by reminding us that structures of individual consciousness and cognition can and do impact the structures of society, particularly if the individual consciousness correlates with a revolutionary class consciousness.

\section{Conclusion}

There are at least two possible conclusions to draw from the argument presented here, neither of which necessarily precludes or excludes the other. One is that Vygotsky did indeed use Lenin's theoretical framework as a starting point, or at least a reference, for his own conceptualization of conscious awareness, scientific concepts, and the role of leadership in cognitive development. The other is that both Lenin and Vygotsky drew on dialectical materialism as an overall guiding theoretical framework, and the end result produced similar conceptual frameworks. Either way, a strong case can and should be made that Vygotsky was indeed part of the Marxist-Leninist theoretical tradition. Both Lenin and Vygotsky were concerned with the pedagogics and processes of the development of conscious awareness, and together they provide a dialectically unified explanation of how the development of consciousness unfolds in both the individual and society. Regardless of which conclusion we draw, it would seem that, more than just merely injecting textual references to Lenin into his publications, and in addition to being Marxist in his analysis, Vygotsky's work in developmental psychology maps onto a Leninist conception of social development.

Despite their theoretical correlation, it is also important to recognize and interrogate the contextual differences of Lenin's and Vygotsky's respective projects. Lenin's work has to be placed historically within the socialist revolution in Russia, specifically the lead-up to the Bolshevik Revolution of 1917. This means that the players in 
Lenin's analysis in What Is to Be Done? were specific to the workers in pre-industrial Russia, the existing ruling class, and the various political factions attempting to determine the best way forward towards a socialist revolution. Lenin's work was focused around a historically specific task, and this specificity certainly shaped how he conceived the process of social change. Likewise, Vygotsky's work must also be similarly situated. Vygotsky was first published just after Lenin died. Soviet socialism had won the day, and the work within the Soviet Union had turned towards continuing the application of Marxism to the sciences (Graham, 1972). In taking up developmental psychology, Vygotsky trained his analytic eye on how children learn and used this as a basis for understanding human development more generally. The players in Vygotsky's analysis, mainly children, were also specific to the context of its field of study. What we do see, however, and where Lenin and Vygotsky find their unity, is in their application of Marxism to their respective endeavors: Lenin was attempting to apply Marxist dialectical materialism (see Lenin, 1972) to the particular social, economic, cultural, and historical conditions of his time and place, just as Vygotsky later attempted to apply Marxist (and perhaps Leninist) theory to developmental psychology. Regardless of their different specific contexts, and again, whether or not we can assert that there was a direct influence of Lenin on Vygotsky, at the least we do see a conceptual unity in Lenin's and Vygotsky's application of dialectical materialist analysis to their respective projects.

To recognize the conceptual unity between Lenin and Vygotsky, however, does not take away from their projects of understanding social and individual development, respectively. Rather, their works, when taken in light of the arguments made here, support each other in very particular ways. In the same way that Lenin's conception of the development of class consciousness is part of a vision of macrosocial transformation, in the best sense, Vygotsky's examination of individual development helps us think more concretely and pedagogically about Lenin's political project at the micro level. By helping us understand how individuals develop and change, Vygotsky's work buttresses Lenin's in that it helps flesh out how changes in social consciousness operate among specific individuals. Additionally, Vygotsky's conceptions help provide Lenin's vanguard with a deeper grasp of the pedagogic and psychological aspects involved in the development of scientific, revolutionary consciousness. In these ways Vygotsky 
essentially gives something back to the theoretical tradition from which he drew: as he took on the work of understanding social consciousness at the individual level, he offers a more nuanced understand of how individuals develop as agents of social change. Perhaps this is Vygotsky's contribution to a larger, more complex answer to Lenin's famous question, What Is to Be Done?

Department of Secondary Education

California State University

Fullerton, CA 92834-6868

wayne.au@sbcglobal.net

\section{REFERENCES}

Bernstein, Basil B. 1996. Pedagogy, Symbolic Control, and Identity: Theory, Research, Critique. Critical Perspectives on Literacy and Education. London/Bristol, Pennsylvania: Taylor \& Francis.

Blanck, Guillermo. 1990. "Vygotsky: The Man and His Cause." Pp. 31-58 in Vygotsky and Education: Instructional Implications and Applications of Sociohistorical Psychology, ed. L. C. Moll. Cambridge, England/New York: Cambridge University Press.

Bourdieu, Pierre 1984 (1979). Distinction: A Social Critique of the Judgment of Taste. Transl. R. Nice. Cambridge, Massachusetts: Routledge \& Kegan Paul.

Bruner, Jerome S. 1984. "Vygotsky's Zone of Proximal Development: The Hidden Agenda." Pp. 93-97 in Children's Learning in the Zone of Proximal Development, ed. B. Rogoff and J. V. Wertsch. San Francisco, California: Jossey-Bass.

. 1987. "Prologue to the English Edition." Pp. 1-16 in The Collected Works of L. S. Vygotsky: Problems of General Psychology, Including the Volume Thinking and Speech, ed. R. W. Rieber and A. Carton. New York: Plenum Press.

Burke, Kenneth. 1950. A Rhetoric of Motives. Berkeley, California: University of California Press.

Chaiklin, Seth. 2003. "The Zone of Proximal Development in Vygotsky's Analysis of Learning and Instruction." Pp. 39-64 in Vygotsky's Educational Theory in Cultural Context, ed. A. Kozulin, B. Gindis, V. S. Ageyev and S. M. Miller. New York: Cambridge University Press.

Cole, Michael, and Sylvia Scribner. 1978. "Introduction." Pp. 1-14 in Mind in Society, by L. S. Vygotsky. Cambridge, Massachusetts: Harvard University Press.

Davydov, Vassily V. 1988a. "The Basic Concepts of Contemporary Psychology.” Soviet Education, 30:8 (August), 15-43.

— 1988b. "From the History of General and Child Psychology." Soviet Education, 30:10 (October), 42-77.

Engels, Frederick. 1940. Dialectics of Nature. Trans. C. Dutt. 1st ed. New York: International Publishers.

Freire, Paulo. 1974. Pedagogy of the Oppressed. Transl. M. B. Ramos. New York: Seabury Press. 
1982. Education for Critical Consciousness. New York: Continuum.

Graham, Loren R. 1972. Science and Philosophy in the Soviet Union. New York: Alfred A. Knopf.

John-Steiner, V., and Holbrook Mahn. 1996. "Sociocultural Approaches to Learning and Development: A Vygotskian Framework." Educational Psychologist, 31, 191-206.

Karpov, Yuriy V. 2003. "Vygotsky's Doctrine of Scientific Concepts: Its Role for Contemporary Education.” Pp. 65-82 in Vygotsky's Educational Theory in Cultural Context, ed. A. Kozulin, B. Gindis, V. S. Ageyev and S. M. Miller. New York: Cambridge University Press.

Lenin, V. I. 1972 (1908). Materialism and Empirio-Criticism. 1st English ed. Peking: Foreign Language Press.

- 1975 (1902). What Is to Be Done?: Burning Questions of Our Movement. Peking: Foreign Language Press.

Marx, Karl, and Frederick Engels. 1978 (1846). The German Ideology. Part I. Pp. 146-200 in The Marx-Engels Reader, edited by R. C. Tucker. New York: W. W. Norton.

Meacham, S. J. 2001. "Vygotsky and the Blues: Re-Reading Cultural Connections and Conceptual Development." Theory Into Practice, 40:3 (Summer), 190.

Nash, Roy. 2005. "The Cognitive Habitus: Its Place in a Realist Account of Inequality/Difference.” British Journal of Sociology of Education, 26:5 (November), 599612.

Newman, Fred, and Lois Holzman. 1993. Lev Vygotsky: Revolutionary Scientist, Critical Psychology. London/New York: Routledge.

Rosa, Alberto, and Ignacio Montero. 1990. “The Historical Context of Vygotsky's Work: A Sociohistorical Approach." Pp. 59-88 in Vygotsky and Education: Instructional Implications and Applications of Sociohistorical Psychology, ed. L. C. Moll. Cambridge, England/New York: Cambridge University Press.

Shandro, Alan. 1995. "'Consciousness from Without': Marxism, Lenin and the Proletariat." Science Eं Society, 59:3 (Fall), 268-297.

Toulmin, Stephen. 1978. "The Mozart of Psychology." New York Review of Books, (September 28).

Vygotsky, Lev S. 1929. "The Problem of the Cultural Development of the Child." Journal of Genetic Psychology: Child Behavior, Animal Behavior, and Comparative Psychology, XXXVI:1 (September), 415-434.

___ 1962. Thought and Language. Transl. E. Hanfmann and G. Vakar. Cambridge, Massachusetts: MIT Press.

- 1978. "Interaction between Learning and Development." Pp. 79-91 in Mind in Society: The Development of Higher Psychological Processes, ed. M. Cole, V. JohnSteiner, S. Scribner and E. Souberman. Cambridge, Massachusetts: Harvard University Press.

- 1981. "The Genesis of Higher Mental Functions." Pp. 144-188 in The Concept of Activity in Soviet Psychology, ed. J. V. Wertsch. Armonk, New York: M. E. Sharpe. . 1986. Thought and Language. Transl. A. Kozulin. 1st ed. Cambridge, Massachusetts: MIT Press.

___ 1987. "Thinking and Speech." Pp. 37-285 in The Collected Works of L.S. 
Vygotsky: Problems of General Psychology, Including the Volume Thinking and Speech, ed. R. W. Rieber and A. Carton. New York: Plenum Press.

Wertsch, James V. 1985. Vygotsky and the Social Formation of Mind. Cambridge, Massachusetts: Harvard University Press. 